\title{
Desain dan Simulasi GMP Fluks Aksial Berbasis Dimensi Magnet Permanen Komersil
}

\author{
PUDJI IRASARI, PUJI WIDIYANTO, MUHAMMAD FATHUL HIKMAWAN
}

\author{
Pusat Penelitian Tenaga Listrik dan Mekatronik \\ Lembaga Ilmu Pengetahuan Indonesia, Indonesia \\ Email: pudj002@lipi.go.id
}

Received 20 Februari 2020 | Revised 28 Maret 2020 | Accepted 3 Mei 2020

\begin{abstract}
ABSTRAK
Makalah ini membahas desain dan simulasi generator magnet permanen fluks aksial 500 W, $220 \mathrm{~V}, 500 \mathrm{rpm}, 1$ fasa, stator tunggal tanpa inti besi lunak dan rotor ganda berbahan baja karbon. Tujuan studi adalah untuk mengetahui performa generator pada dua jenis pembebanan yaitu beban $R_{\mathrm{L}}$ dan $Z_{\mathrm{L}}$. Metode perhitungan desain dilakukan secara analitik dan numerik menggunakan perangkat lunak FEMM 4.2 dengan berbasis pada dimensi magnet permanen komersil. Performa generator yang dianalisis meliputi tegangan terminal, daya keluaran dan efisiensi. Hasil simulasi menunjukkan bahwa ketika diberi beban $R_{L}$, daya keluaran dan efisiensi generator lebih tinggi dibanding ketika diberi beban $Z_{L}$. Grafik tegangan terminal dari kedua jenis pembebanan tersebut sebagian berimpit tetapi pada beban $R_{L}$ tingkat penurunannya lebih tajam disebabkan tegangan jatuhnya lebih besar. Dari semua hasil perhitungan dan simulasi, dapat disimpulkan bahwa generator menunjukkan performa yang baik pada kedua jenis pembebanan dengan efisiensi sekitar $80 \%$.
\end{abstract}

Kata kunci: generator, magnet permanen, fluks aksial, stator tunggal, rotor ganda

\begin{abstract}
This paper discusses the design and simulation of $500 \mathrm{~W}, 220 \mathrm{~V}, 500 \mathrm{rpm}$ axial flux permanent magnet generators, with the construction of coreless, single stator, and double rotor made of carbon steel. This study aims to find out the performance of the generators in two types of loadings, namely $R_{\mathrm{L}}$ and $Z_{\mathrm{L}}$ loads. The design calculation method is done analytically and numerically using FEMM 4.2 software based on the dimensions of commercial permanent magnets. The generator performances analyzed include the terminal voltage, the output power, and the efficiency. From the simulation results, it is known that under load $R_{\mathrm{L}}$, the output power and efficiency are higher than under load $Z$ L. The terminal voltage graphs of the two types of loadings partially coincide but at the $R_{\mathrm{L}}$ load, the rate of the decline is sharper due to the greater voltage drop. From all the results, it can be concluded that the generator shows good performance on both types of loads with a quite high efficiency, which is around $80 \%$.
\end{abstract}

Keywords: generator, permanent magnet, axial flux, single stator, double rotor 
Desain dan Simulasi GMP Fluks Aksial Berbasis Dimensi Magnet Permanen Komersil

\section{PENDAHULUAN}

Sebagai negara tropis, Indonesia tidak memiliki kecepatan angin rata-rata yang tinggi seperti halnya negara-negara subtropis. Kecepatan angin Indonesia cukup rendah, yakni berada pada kisaran 2,5 - $6 \mathrm{~m} / \mathrm{s}$ (Dewata, dkk, 2015). Berdasarkan hasil pengukuran (Dida, dkk, 2016), kecepatan angin sebesar $6-12 \mathrm{~m} / \mathrm{s}$ terjadi khususnya di perairan sebelah selatan khatulistiwa. Di wilayah-wilayah dengan kecepatan angin yang relatif kecil, pemanfaatan energi angin untuk pembangkit listrik dilakukan dengan membuat turbin angin skala kecil berkapasitas puluhan hingga ratusan watt. Konstruksi turbin angin juga cukup sederhana sehingga memungkinkan untuk dikerjakan oleh bengkel atau industri kecil lokal.

Penguasaan teknologi turbin angin makin banyak dilakukan di Indonesia sejak tersedianya magnet permanen NdFeB secara komersial dengan harga yang semakin terjangkau. Magnet NdFeB mempermudah desainer dalam merancang generator dengan kutub banyak untuk menghasilkan kecepatan yang sangat rendah. Dengan demikian generator dan baling-baling turbin tidak perlu dihubungkan melalui transmisi mekanik atau dapat dihubungkan langsung dalam satu poros.

Ditinjau dari arah fluks magnet di celah udara, Generator Magnet Permanen (GMP) ada dua jenis, yaitu GMP fluks aksial dan fluks radial. Salah satu kelemahan GMP adalah adanya torsi cogging yang disebabkan oleh gaya tarik menarik antara fluks magnet rotor dengan gigi stator. Pada daerah dengan kecepatan angin rendah, torsi cogging menjadi masalah karena dibutuhkan kecepatan angin yang lebih tinggi untuk mulai memutar turbin (cut-in wind speed). Torsi cogging dapat dieliminir dengan menggunakan stator tanpa gigi (toothless stator) atau tanpa inti besi lunak (coreless stator). Kedua konstruksi tersebut banyak dijumpai pada Generator Magnet Permanen Fluks Aksial (GMPFA). Tidak adanya gigi dan inti besi lunak membuat proses manufaktur generator menjadi lebih mudah. Untuk menyatukan atau menempatkan lilitan, bahan non-magnetik seperti resin, umumnya digunakan.

Penelitian dan pengembangan teknologi turbin angin skala kecil telah banyak dilakukan di Indonesia, baik itu berupa penelitian komponen maupun sistem. Salah satu penelitian sistem turbin angin dilakukan oleh (Nakhoda \& Saleh, 2016) dengan membuat turbin angin sumbu vertikal model Savonius dan generatornya dari jenis GMPFA stator tunggal dan rotor tunggal. GMPFA didesain untuk membangkitkan daya $615 \mathrm{~W}$ pada $50 \mathrm{~Hz}$. Pembuatan dan pengujian GMPFA stator tunggal dan rotor tunggal dilakukan oleh (Wijaya, W., \& Nugroho, 2014). Dalam penelitian ini generator didesain dengan 24 kutub, statornya tanpa inti besi lunak, dan dari hasil uji diperoleh daya keluaran sebesar $28.99 \mathrm{~W}$ pada $50 \mathrm{~Hz}$. Penelitian lain terkait GMPFA dilakukan oleh (Kasim, dkk, 2016) dan (Wirtayasa, dkk, 2017). Selain itu, (Kasim, dkk., 2016) juga mengkaji dampak variasi lebar celah udara terhadap performa generator. Kontrol daya turbin angin skala kecil 500 W, 3 fasa, 180 V, 3A, dibuat dan diuji oleh (Robiansyah, 2017).

Dalam makalah ini akan didesain dan disimulasikan GMPFA 1 fasa, 500 W, 500 rpm, 220 V, stator tunggal, rotor ganda. Studi dilakukan untuk mengetahui performa generator dalam kondisi berbeban resistif murni $R_{\mathrm{L}}$ dan resistif-induktif dihubung seri $\left(Z_{\mathrm{L}}\right)$.

Desain dilakukan berbasis pada dimensi magnet permanen komersil yang dapat diperoleh dari penyedia daring dalam negeri. Permasalahan yang perlu diperhatikan ketika mendesain dengan ukuran dan kekuatan magnet yang sudah ditetapkan adalah bahwa lebar kutub stator tidak dapat ditentukan mengikuti keinginan perancang. Ada batasan nilai rasio lebar kutub rotor terhadap kutub stator yang harus dipenuhi bila ingin mendapatkan performa mesin yang baik. Dengan terbatasnya lebar kutub stator berarti terbatas pula ruang untuk lilitan yang 
menyebabkan variasi jumlah dan diameter lilitan yang dapat disusun juga menjadi terbatas. Kondisi tersebut menyebabkan daya dan tegangan menjadi kontradiktif, artinya bila besarnya tegangan telah terpenuhi tetapi diinginkan daya yang lebih besar maka diameter lilitan harus diperbesar atau sebaliknya bila besarnya daya telah tercapai tetapi diinginkan tegangan yang lebih tinggi maka jumlah lilitan harus diperbanyak. Apabila ruang yang tersedia tidak cukup untuk menampung dua kebutuhan tersebut sekaligus maka hanya salah satu parameter yang dapat dipenuhi, umumnya adalah tegangan dengan pertimbangan bahwa kekurangan daya dapat diatasi dengan menambah jumlah unit generator. Metode perhitungan desain dalam studi ini akan dilakukan secara analitik dan numerik menggunakan perangkat lunak FEMM 4.2. Performa generator yang dianalisis meliputi tegangan terminal, daya keluaran dan efisiensi.

\section{METODOLOGI PENELITIAN}

\subsection{Pemilihan Tipe Rotor}

Sebelum melakukan perhitungan desain, tipe rotor harus ditetapkan terlebih dahulu. Gambar 1 memperlihatkan topologi GMPFA stator tunggal tanpa inti besi lunak dan rotor ganda yang memperlihatkan posisi seluruh komponen utamanya.

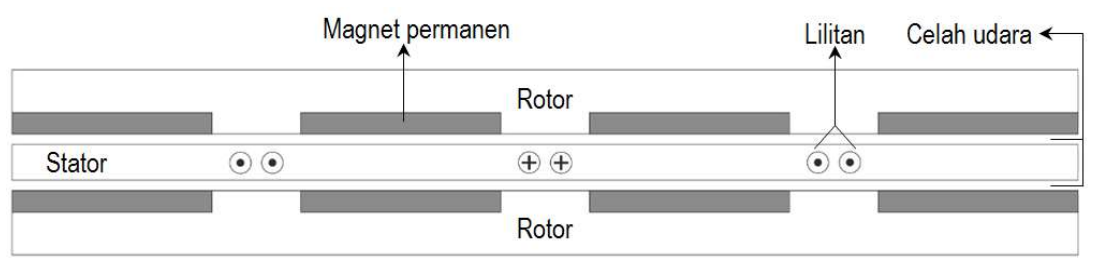

\section{Gambar 1. Topologi GMPFA}

Stator merupakan bagian yang statis atau diam, berbentuk piringan yang terbuat dari bahan non-magnetis dan berfungsi sebagai tempat lilitan kawat tembaga. Rotor adalah bagian yang berputar, berbentuk piringan dari baja karbon atau laminasi baja listrik dan di dalamnya disusun magnet permanen.

Dari Gambar 1 dapat dilihat bahwa tipe rotor yang digunakan adalah tipe inset, yaitu bagian ketebalan magnet permanen ditanam dalam piringan rotor sehingga hanya permukaannya saja yang nampak di celah udara. Tipe rotor lain yang juga banyak digunakan adalah tipe rotor yang magnet permanennya direkatkan pada permukaan piringan (surface permanent magnet rotor). Tipe tersebut lebih mudah dimanufaktur tetapi memiliki resiko lebih tinggi dalam hal magnet permanen terlepas dari tempat kedudukannya saat generator berputar. Berdasarkan pertimbangan tersebut maka tipe rotor inset yang dipilih dalam studi ini.

\subsection{Penentuan Parameter Awal Desain}

Parameter awal desain atau biasa disebut juga dengan parameter masukan terdiri dari parameter mekanikal dan elektrikal. Parameter awal mekanikal berupa dimensi dari komponen utama generator, yaitu stator dan rotor. Kedua komponen tersebut dianggap sebagai komponen utama karena terkait langsung dengan proses konversi energi listrik. Dimensi dari komponen utama yang harus dihitung adalah dimensi arah radial dan arah aksial seperti diperlihatkan pada Gambar 2(a) \& (b). 


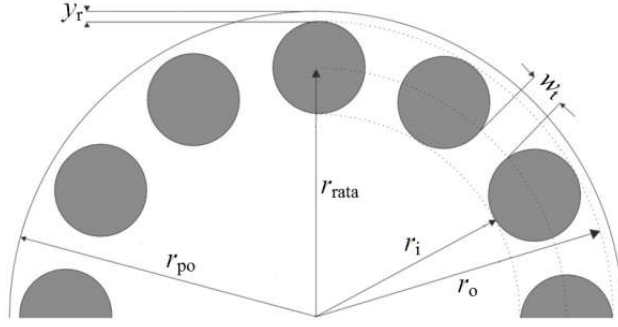

(a)

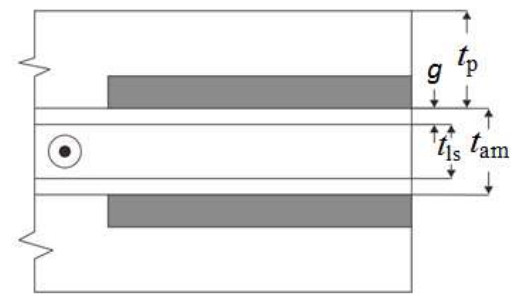

(b)

Gambar 2. Dimensi GMPFA, (a) Dimensi Arah Radial (b) Dimensi Arah Aksial

Prosedur desain GMPFA berbasis pada dimensi magnet permanen dilakukan mengikuti tahapan yang ditunjukkan oleh diagram alir pada Gambar 3.

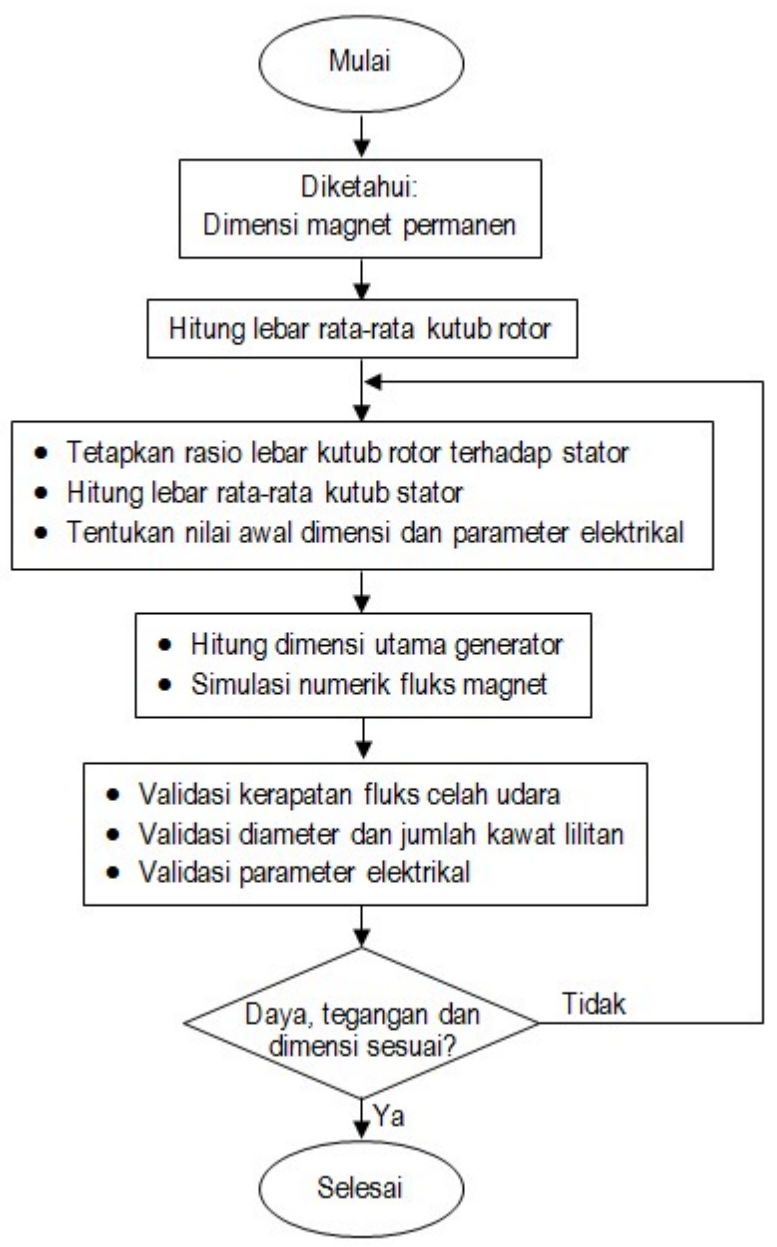

Gambar 3. Diagram Alir Desain GMPFA Berbasis pada Dimensi Magnet Permanen

Lebar kutub rotor rata-rata $b_{\mathrm{p}(\text { rata) }}$ diperoleh dengan menghitung nilai rata-rata dari $b_{\mathrm{p}(\mathrm{r} 1) \text {-(r3) }}$ dimana $b_{\mathrm{p}(\mathrm{r} 2)}$ adalah lebar busur yang dihasilkan oleh $r_{\text {rata }}$ pada kutub rotor. Dengan cara yang sama, $b_{\mathrm{p}(\mathrm{r} 1)}$ dan $b_{\mathrm{p}(\mathrm{r} 3)}$ adalah lebar busur pada jari-jari yang bersesuaian r1 dan r3. Lilitan stator 
berbentuk lingkaran mengikuti bentuk magnet permanen. Apabila GMPFA dibentangkan, maka lebar kutub stator dan rotor dapat dilihat seperti pada Gambar 4.

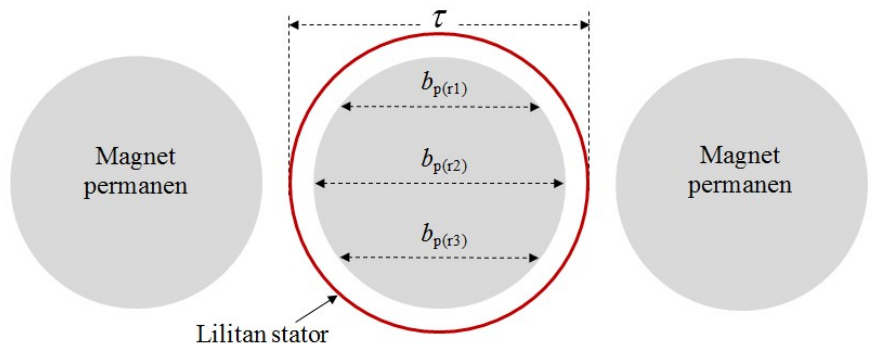

Gambar 4. Lebar kutub stator dan rotor

Besarnya lebar kutub stator $\tau$ adalah

$$
\tau=\frac{2 \pi r_{\text {rata }}}{2 p}
$$

dengan $p=$ jumlah pasang kutub.

Lebar kutub stator rata-rata $\tau_{\text {(rata) }}$ dihitung dengan cara yang sama seperti mendapatkan $b_{p \text { (rata). }}$. Selanjutnya rasio lebar kutub rotor terhadap kutub stator $\alpha_{\mathrm{i}}$ :

$$
\alpha_{\mathrm{i}}=\frac{B_{\text {rata }}}{B_{m g}}=\frac{b_{\mathbf{p}(\text { rata })}}{\tau_{(\text {rata })}}
$$

dimana $B_{\text {rata }}=$ kerapatan fluks celah udara rata-rata, $B_{\mathrm{mg}}=$ kerapatan fluks celah udara maksimum.

Nilai $\alpha_{\mathrm{i}}$ berada pada rentang 0,55 $<\alpha_{\mathrm{i}}<1$ (Dalcali \& Akbaba, 2017) (Gieras, 2010). Nilai tersebut berpengaruh terhadap bentuk gelombang tegangan yang diinduksikan ke lilitan stator yang merupakan fungsi dari gelombang kerapatan fluks magnet di celah udara. Dalam studi ini, $\alpha_{\mathrm{i}}$ ditetapkan sekitar 0,85.

Dari nilai $\alpha_{\mathrm{i}}$ tersebut dapat diperoleh sebagian besar dimensi generator arah radial. Selanjutnya nilai awal parameter elektrikal juga ditetapkan, dan seluruh nilai awal untuk perhitungan desain ditampilkan dalam Tabel 1.

\begin{tabular}{|c|c|c|c|c|c|}
\hline Parameter, simbol & Nilai & Satuan & Parameter, simbol & Nilai & Satuan \\
\hline \multicolumn{3}{|l|}{ Dimensi } & \multicolumn{3}{|l|}{ Parameter elektrikal } \\
\hline Diameter magnet, $d_{m}$ & 0.030 & $\mathrm{~m}$ & Daya keluaran, $P_{0}$ & 500 & W \\
\hline Tebal magnet, $t_{\mathrm{m}}$ & 0.003 & $\mathrm{~m}$ & Tegangan terminal, $V$ & 220 & $\mathrm{~V}$ \\
\hline Jarak antar magnet, $w_{t}$ & 0.004 & $\mathrm{~m}$ & Faktor daya, $\cos \theta$ & 0.85 & \\
\hline Jari-jari dalam magnet, $r_{\mathrm{i}}$ & 0.050 & $\mathrm{~m}$ & Efisiensi, $\eta$ & 0.8 & $\%$ \\
\hline Jari-jari luar magnet, $r_{0}$ & 0.080 & $\mathrm{~m}$ & Frekuensi, $f$ & 50 & $\mathrm{~Hz}$ \\
\hline Jari-jari rata-rata magnet, $r_{\text {rata }}$ & 0.065 & $\mathrm{~m}$ & Jumlah pasang kutub, $p$ & 6 & pasang \\
\hline Lebar celah udara, $g$ & 0.001 & $\mathrm{~m}$ & Jumlah kutub, $2 p$ & 12 & kutub \\
\hline Tebal piringan rotor, $t_{p}$ & 0.007 & $\mathrm{~m}$ & Jumlah fasa, $m$ & 1 & fasa \\
\hline Jumlah alur stator, $S_{1}$ & 12 & alur & Jumlah koil/kutub/fasa, $q$ & 1 & \\
\hline
\end{tabular}

Tabel 1. Nilai Awal Desain GMPFA

Lebar yoke rotor $y_{r}$ dan tebal piringan $t_{p}$ dihitung secara bersamaan. Dua dimensi tersebut harus dapat menjamin bahwa kerapatan fluks magnet yang melalui yoke rotor $B_{\mathrm{yr}}$ berada di 
bawah saturasi atau kejenuhan magnetik material. Hubungan antara ketiga parameter $y_{r}, t_{p}$, dan $B_{\text {yr }}$ dinyatakan dalam Persamaan (3) (Boldea, 2006):

$$
B_{\mathrm{yr}}=\frac{\Phi_{\mathrm{f}}}{2 y_{\mathrm{r}} t_{\mathrm{p}}}
$$

dimana $\Phi_{k}=$ fluks magnet di celah udara $(\mathrm{T})$ dan $B_{\mathrm{yr}}$ ditetapkan sebesar $1 \mathrm{~T}$.

Material piringan rotor umumnya adalah baja dengan kandungan karbon yang sangat rendah. Baja karbon banyak digunakan karena memiliki karakteristik mekanik yang baik dan harganya murah (Tumanski, 2011). Dalam studi ini, bahan magnetik lunak yang digunakan untuk piringan rotor adalah baja karbon 1117 yang karakteristiknya diperoleh dari pustaka perangkat lunak FEMM 4.2 dan diperlihatkan pada Gambar 5.

Jari-jari luar piringan $r_{\mathrm{po}}$ :

$$
r_{\mathrm{po}}=r_{\mathrm{o}}+y_{r}
$$

Tebal aksial lilitan stator $t_{\mathrm{s}}$ dan jarak antar permukaan magnet $t_{\mathrm{am}}$ dapat diketahui setelah diperoleh besarnya diameter dan jumlah lilitan melalui perhitungan parameter elektrikal.

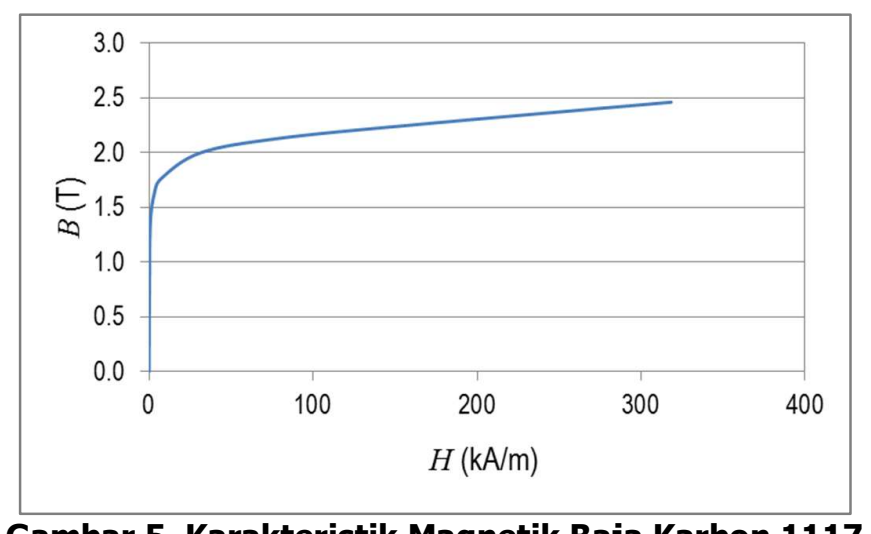

Gambar 5. Karakteristik Magnetik Baja Karbon 1117

\subsection{Perhitungan Parameter Elektrikal}

Arus jangkar $I_{\mathrm{a}}$ dan diameter kawat lilitan $d_{\mathrm{w}}$ dihitung dengan persamaan (Gieras, dkk, 2008) (Irasari, dkk, 2013):

$$
\begin{gathered}
I_{a}=\frac{P_{o}}{m V \eta \cos \theta} \\
A_{w}=\frac{I_{a}}{J} \\
d_{w}=\sqrt{\frac{4 A_{w}}{\pi}}
\end{gathered}
$$

dimana: $A_{\mathrm{w}}=$ luas penampang kawat lilitan $\left(\mathrm{mm}^{2}\right), J=$ kerapatan arus $\left(\mathrm{A} / \mathrm{mm}^{2}\right)$, ditetapkan $J=3 \mathrm{~A} / \mathrm{mm}^{2}$.

Besarnya tegangan induksi $E_{f}$ ketika fluks magnet di celah udara $\Phi_{\sharp}$ berputar dengan frekuensi $f$ dan memotong lilitan stator adalah: 


$$
\begin{gathered}
E_{\mathrm{f}}=4.44 f N_{1} k_{\mathrm{w} 1} \Phi_{\mathrm{f}} \\
\Phi_{\mathrm{f}}=\alpha_{\mathrm{i}} B_{\mathrm{mg}} \frac{\pi}{8 p} D_{\mathrm{o}}^{2}\left(1-k_{\mathrm{d}}^{2}\right) \\
B_{\mathrm{mg}}=\frac{B_{\mathrm{r}}}{1+\left[\mu_{\mathrm{rrec}}\left(g+0.5 t_{\mathrm{ls}}\right) / t_{\mathrm{m}}\right] k_{\mathrm{sat}}} \\
k_{\mathrm{d}}=\frac{r_{\mathrm{i}}}{r_{\mathrm{o}}}
\end{gathered}
$$

dimana $N_{1}=$ jumlah lilitan seri dalam 1 fasa, $k_{\mathrm{w} 1}=$ faktor lilit pada harmonik fundamental, $D_{0}$ $=2 \times r_{0}, \mu_{\text {rrec }}=$ permeabilitas relatif magnet $=1,05, B_{\mathrm{mg}}=$ kerapatan fluks maksimum di celah udara $(\mathrm{T}), B_{\mathrm{r}}=$ kerapatan fluks remanensi $=1,4 \mathrm{~T}, k_{\mathrm{sat}}=$ faktor jenuh magnetik material yang nilainya $k_{\text {sat }} \geq 1$.

$B_{\mathrm{mg}}$ pada Persamaan (10) divalidasi melalui simulasi fluks magnetik menggunakan perangkat lunak FEMM 4.2. Dari simulasi tersebut juga akan diperoleh bentuk gelombang kerapatan fluks magnet di celah udara serta pola distribusi fluks magnet pada stator dan rotor.

Resistansi kawat lilitan $R_{1}$, reaktansi bocor alur $X_{1}$ serta reaktansi bersama $X_{\mathrm{a}}$ sumbu $\mathrm{d}$ dan q dihitung dengan persamaan:

$$
\begin{gathered}
R_{1}=\frac{\rho L_{w}}{A_{w}} \\
X_{1}=4 \pi f \mu_{0} \frac{L_{\mathrm{i}} N_{1}^{2}}{p q}\left(\lambda_{\mathrm{s}}+\frac{l_{1 \mathrm{e}}}{L_{\mathrm{i}}} \lambda_{\mathrm{e}}+\lambda_{1 \mathrm{~d}}\right) \\
X_{\mathrm{ad}}=2 m \mu_{0} f\left(\frac{N_{1} k_{\mathrm{w} 1}}{p}\right)^{2} \frac{\left(r_{\mathrm{o}}^{2}-r_{\mathrm{i}}^{2}\right)}{g^{\prime}} k_{\mathrm{fd}} \\
X_{\mathrm{aq}}=2 m \mu_{0} f\left(\frac{N_{1} k_{\mathrm{w} 1}}{p}\right)^{2} \frac{\left(r_{\mathrm{o}}^{2}-r_{\mathrm{i}}^{2}\right)}{g_{\mathrm{q}}^{\prime}} k_{\mathrm{fq}}
\end{gathered}
$$

dimana $\rho=$ massa jenis tembaga $=1,72 \times 10^{-8}(\Omega . \mathrm{m}), L_{\mathrm{w}}=$ panjang kawat lilitan $(\mathrm{m}), L_{\mathrm{i}}=$ panjang efektif lilitan stator arah radial, $\lambda_{s}=$ permeansi bocor alur, $\lambda_{\mathrm{e}}=$ permeansi bocor ujung lilitan, $\lambda_{1 \mathrm{~d}}=$ permeansi fluks bocor diferensial, $g^{\prime}$ dan $g_{q}^{\prime}=$ celah udara ekuivalen sumbu $\mathrm{d}$ dan sumbu $\mathrm{q}, k_{\mathrm{fd}}$ dan $k_{\mathrm{fq}}=$ faktor bentuk reaksi jangkar sumbu $\mathrm{d}$ dan $\mathrm{q}$.

Faktor bentuk reaksi jangkar didefinisikan sebagai rasio amplitudo kerapatan fluks pada harmonik pertama terhadap nilai maksimum komponen normal kerapatan fluks reaksi jangkar. Untuk rotor tipe inset, $k_{\mathrm{fd}}$ dan $k_{\mathrm{fq}}$ dihitung dengan persamaan:

$$
\begin{gathered}
k_{f d}=\frac{1}{\pi}\left[\alpha_{\mathrm{i}} \pi+\sin \alpha_{\mathrm{i}} \pi+c_{g}\left(\pi-\alpha_{\mathrm{i}} \pi-\sin \alpha_{\mathrm{i}} \pi\right)\right] \\
k_{\mathrm{fq}}=\frac{1}{\pi}\left[\frac{1}{c_{\mathrm{g}}}\left(\alpha_{\mathrm{i}} \pi-\sin \alpha_{\mathrm{i}} \pi\right)+\pi\left(1-\alpha_{\mathrm{i}}\right)+\sin \alpha_{\mathrm{i}} \pi\right] \\
c_{\mathrm{g}}=1+h / g
\end{gathered}
$$

dimana $h=$ kedalaman magnet permanen ditanam dalam piringan rotor (m). 
Reaktansi sinkron $X_{\mathrm{s}}$ dan arus jangkar $I_{\mathrm{a}}$ pada sumbu $\mathrm{d}$ dan $\mathrm{q}$, diperoleh menggunakan persamaan:

$$
\begin{gathered}
X_{\mathrm{sd}}=X_{\mathrm{ad}}+X_{1} \\
X_{\mathrm{sq}}=X_{\mathrm{aq}}+X_{1} \\
I_{\mathrm{ad}}=\frac{E_{\mathrm{f}}\left(X_{\mathrm{sq}}+X_{\mathrm{L}}\right)}{\left(X_{\mathrm{sd}}+X_{\mathrm{L}}\right)\left(X_{\mathrm{sq}}+X_{\mathrm{L}}\right)+\left(R_{1}+R_{\mathrm{L}}\right)^{2}} \\
I_{\mathrm{aq}}=\frac{E_{\mathrm{f}}\left(R_{1}+R_{\mathrm{L}}\right)}{\left(X_{\mathrm{sd}}+X_{\mathrm{L}}\right)\left(X_{\mathrm{sq}}+X_{\mathrm{L}}\right)+\left(R_{1}+R_{\mathrm{L}}\right)^{2}} \\
I_{\mathrm{a}}=\sqrt{I_{\mathrm{ad}}^{2}+I_{\mathrm{aq}}^{2}}
\end{gathered}
$$

Besarnya tegangan terminal adalah:

$$
V=\sqrt{\left(E_{\mathrm{f}}-I_{\mathrm{a}} R_{1}\right)^{2}-\left(I_{\mathrm{a}} X_{\mathrm{sq}}\right)^{2}-\left(I_{\mathrm{a}} X_{\mathrm{sd}}\right)^{2}}
$$

Daya, rugi daya serta efisiensi dihitung dengan persamaan-persamaan berikut:

$$
\begin{gathered}
P_{\text {elm }}=m E_{\mathrm{f}} I_{\mathrm{a}} \cos \psi \\
\psi=\arccos \left(\frac{I_{\mathrm{aq}}}{I_{\mathrm{a}}}\right) \\
P_{\mathrm{o}}=P_{\mathrm{elm}}-P_{\text {rugi }} \\
P_{\text {rugi }}=P_{\mathrm{cu}}+P_{\mathrm{c}}+P_{\text {fric }}+P_{\mathrm{wd}} \\
\eta=\frac{P_{\mathrm{o}}}{P_{\text {elm }}} \times 100 \%
\end{gathered}
$$

$P_{\text {elm }}=$ daya elektro magnetik $(\mathrm{W}), \psi=$ sudut daya beban, $\cos \psi=$ faktor daya beban, $P_{\text {rugi }}=$ rugi daya total $(\mathrm{W}), P_{\mathrm{cu}}=$ rugi tembaga $(\mathrm{W}), P_{\mathrm{c}}=$ rugi inti $(\mathrm{W}), P_{\text {fric }}=$ rugi gesekan bantalan poros, $P_{\mathrm{wd}}=$ rugi hambatan angin di celah udara $(\mathrm{W}), \eta=$ efisiensi $(\%)$.

\section{HASIL DAN PEMBAHASAN}

\subsection{Hasil Perhitungan Parameter Elektrikal}

Proses perhitungan parameter elektrikal secara analitik dan numerik merupakan satu kesatuan karena $B_{\mathrm{mg}}$ divalidasi melalui simulasi magnetik. Apabila terjadi perbedaan nilai $B_{\mathrm{mg}}$ setelah validasi maka $N_{1}$ harus disesuaikan untuk mendapatkan tegangan yang diinginkan (Persamaan (8) dan (24)). Selain itu $d_{w}$ juga divalidasi untuk disesuaikan dengan diameter kawat yang tersedia di pasar komersil. Berdasarkan nilai awal desain pada Tabel 1, hasil perhitungan parameter elektrikal ditampilkan dalam Tabel 2. 
Tabel 2. Perbandingan Nilai Awal dan Nilai Validasi Parameter Elektrikal

\begin{tabular}{|l|r|r|l|}
\hline \multicolumn{1}{|c|}{ Parameter, simbol } & Nilai awal & Nilai validasi & \multicolumn{1}{c|}{ Satuan } \\
\hline Daya keluaran, $P_{0}$ & 500 & 579,64 & W \\
\hline Arus jangkar, $I_{\mathrm{a}}$ & 3,34 & 3,14 & $\mathrm{~A}$ \\
\hline Diameter kawat lilitan, $d_{\mathrm{w}}$ & 2,09 & 2 & $\mathrm{~mm}$ \\
\hline Tegangan terminal, $V$ & 220 & 224,27 & V \\
\hline Jumlah lilitan, $N_{1}$ & 600 & 540 & lilit \\
\hline
\end{tabular}

Parameter elektrikal yang lain, yakni resistansi, reaktansi dan rugi-rugi daya yang dihitung berdasarkan nilai $B_{\mathrm{mg}}, d_{\mathrm{w}}$ dan $N_{1}$ yang telah divalidasi, hasilnya diperlihatkan dalam Tabel 3.

Tabel 3. Hasil Perhitungan Resistansi, Reaktansi dan Rugi Daya

\begin{tabular}{|l|r|l|}
\hline \multicolumn{1}{|c|}{ Parameter, simbol } & Nilai & Satuan \\
\hline Resistansi stator, $R_{1}$ & $0,3 \times 10^{-3}$ & $\Omega$ \\
\hline Reaktansi stator, $X_{1}$ & 0,333 & $\Omega$ \\
\hline Reaktansi bersama sumbu d, $X_{\text {ad }}$ & 0,171 & $\Omega$ \\
\hline Reaktansi bersama sumbu q, $X_{\text {aq }}$ & 0,077 & $\Omega$ \\
\hline Reaktansi sinkron sumbu d, $X_{\text {sd }}$ & 0,504 & $\Omega$ \\
\hline Reaktansi sinkron sumbu q, $X_{\text {sq }}$ & 0,410 & $\Omega$ \\
\hline Rugi tembaga, $P_{\mathrm{cu}}$ & $2,9 \times 10^{-3}$ & W \\
\hline Rugi inti, $P_{\mathrm{c}}$ & 120,59 & $\mathrm{~W}$ \\
\hline Rugi hambatan angin, $P_{\mathrm{wd}}$ & $7,9 \times 10^{-3}$ & $\mathrm{~W}$ \\
\hline Rugi gesekan bantalan poros, $P_{\text {fric }}$ & 4,35 & $\mathrm{~W}$ \\
\hline
\end{tabular}

Rugi gesekan bantalan poros dihitung dengan asumsi berat poros sama dengan $10 \%$ berat piringan.

\subsection{Hasil Simulasi Fluks Magnetik}

Simulasi magnetik dilakukan pada $I_{a}=3,14$ A, hasilnya diperlihatkan pada Gambar 6 .

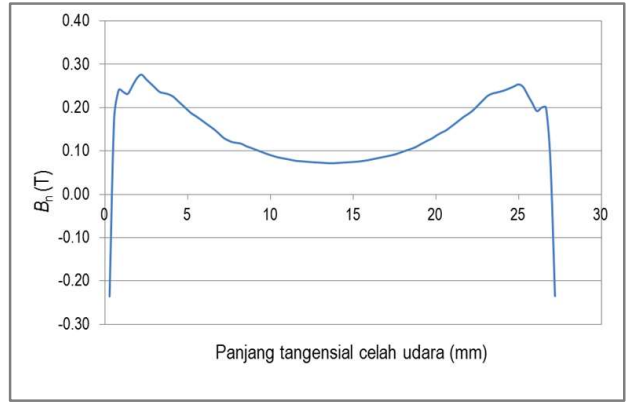

(a)

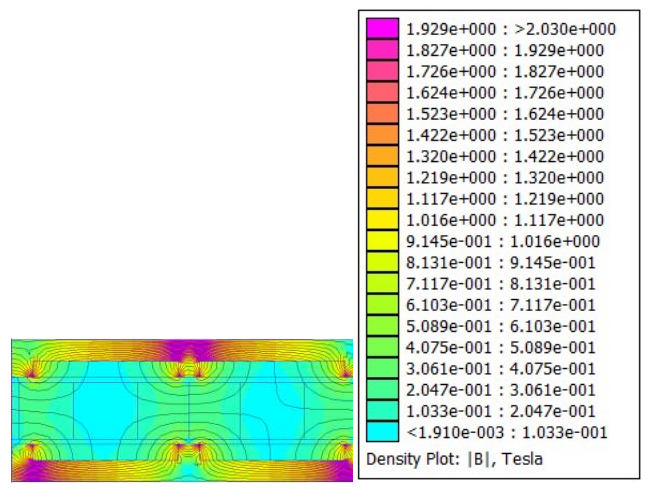

(b)

Gambar 6. Hasil Simulasi Fluks Magnet (a) Kerapatan Fluks Magnet di Celah Udara (b) Distribusi Fluks Magnet pada Stator dan Rotor

Kerapatan fluks magnet hanya dapat diperoleh dari satu sisi celah udara. Amplitudo maksimum terjadi ketika fluks magnet rotor berada di tengah kutub stator (Gambar 6(a)). Dari simulasi ini didapat nilai rata-rata kerapatan fluks celah udara komponen normal $B_{n}=0,1466 \mathrm{~T}$. Mengacu pada Persamaan (2), $B_{\mathrm{n}}=B_{\mathrm{rata}}$, sehingga $B_{\mathrm{mg}}$ validasi $=2$ sisi celah udara $\times B_{\mathrm{n}} / \alpha_{\mathrm{i}}=$ 
0,3421 T. Dibandingkan dengan nilai awal $B_{\mathrm{mg}}=0,3106 \mathrm{~T}$, terdapat perbedaan sekitar 9,2\%. Agar tegangan tetap mendekati $220 \mathrm{~V}$, nilai $N_{1}$ dikoreksi dan diperoleh angka yang paling optimum adalah 540 lilit. Hasil akhir untuk $V$ sedikit lebih tinggi dibanding $V$ awal (Tabel 2).

Gambar 6(b) memperlihatkan distribusi fluks magnet pada stator dan rotor dengan pola yang teratur. Kerapatan fluks magnet maksimum pada rotor sebesar 1,929 T masih berada di bawah tingkat kejenuhan magnetik baja karbon 1117.

\subsection{Hasil Simulasi Karakteristik GMPFA}

Performa GMPFA tanpa beban $(V=0)$ digambarkan dalam bentuk Grafik $E_{\mathrm{f}}$ sebagai fungsi frekuensi $f$ (Gambar 7). Dalam kondisi ini, tegangan yang dibangkitkan generator adalah tegangan induksi $E_{f}$ yang memiliki hubungan proporsional terhadap $f$.

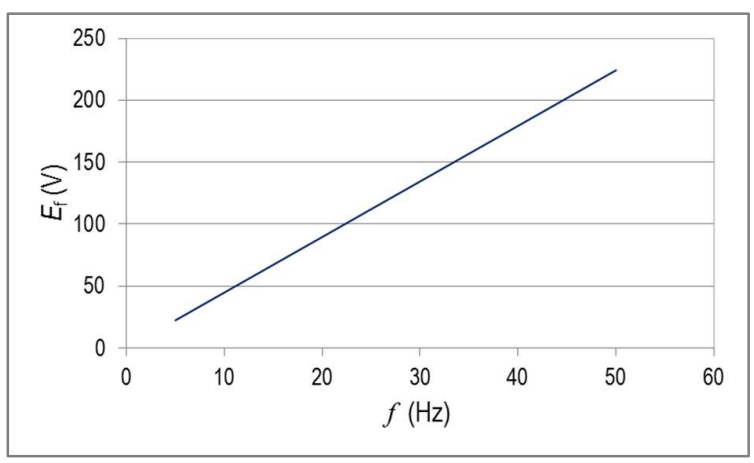

\section{Gambar 7. Karakteristik Generator tanpa Beban}

Karakteristik berbeban diperoleh dengan memberikan beban $R_{\mathrm{L}}$ dan $Z_{\mathrm{L}}$ pada generator. Pada beban $Z_{\mathrm{L}}$, nilai $R_{\mathrm{L}}$ yang diberikan sama dengan ketika diberi beban $R_{\mathrm{L}}$ murni sedangkan nilai induktansi $L$ dinaikkan secara bertahap. Pengaruh pembebanan terhadap $V_{1} P_{0}$ serta $\eta$ ditampilkan dalam Tabel 4 dan 5.

Tabel 4. Hasil Perhitungan Parameter Elektrikal pada Variasi Beban $\boldsymbol{R}_{\mathbf{L}}$

\begin{tabular}{|c|c|c|c|c|c|c|c|}
\hline $\boldsymbol{R}_{\mathrm{L}}(\boldsymbol{\Omega})$ & $\boldsymbol{I}_{\mathrm{ad}}(\mathbf{A})$ & $\boldsymbol{I}_{\mathrm{aq}}(\mathbf{A})$ & $\boldsymbol{I}_{\mathrm{a}}(\mathbf{A})$ & $\boldsymbol{V}(\mathbf{V})$ & $\boldsymbol{P}_{\text {elm }}(\mathbf{W})$ & $\boldsymbol{P}_{\mathrm{o}}(\mathrm{W})$ & $\eta(\%)$ \\
\hline 70 & 0.02 & 3.20 & 3.20 & 224.276 & 718.56 & 593.61 & 82.61 \\
\hline 80 & 0.01 & 2.80 & 2.80 & 224.277 & 628.75 & 503.79 & 80.13 \\
\hline 90 & 0.01 & 2.49 & 2.49 & 224.277 & 558.89 & 433.94 & 77.64 \\
\hline 100 & 0.01 & 2.24 & 2.24 & 224.278 & 503.01 & 378.05 & 75.16 \\
\hline 110 & 0.01 & 2.04 & 2.04 & 224.278 & 457.28 & 332.32 & 72.67 \\
\hline 120 & 0.01 & 1.87 & 1.87 & 224.279 & 419.17 & 294.22 & 70.19 \\
\hline
\end{tabular}

Tabel 5. Hasil Perhitungan Parameter Elektrikal pada Variasi Beban $Z_{\mathrm{L}}$

\begin{tabular}{|c|c|c|c|c|c|c|c|c|c|c|c|}
\hline $\boldsymbol{R}_{\mathrm{L}}(\Omega)$ & $\boldsymbol{L}(\mathbf{H})$ & $\boldsymbol{X}_{\mathrm{L}}(\Omega)$ & $\mathbf{Z}_{\mathrm{L}}(\Omega)$ & $\boldsymbol{I}_{\mathrm{ad}}(\mathrm{A})$ & $\boldsymbol{I}_{\mathrm{aq}}(\mathrm{A})$ & $\boldsymbol{I}_{\mathrm{a}}(\mathrm{A})$ & $\boldsymbol{V}(\mathbf{V})$ & $\cos \Psi$ & $\boldsymbol{P}_{\text {elm }}(\mathrm{W})$ & $\boldsymbol{P}_{\mathrm{o}}(\mathrm{W})$ & $\eta(\%)$ \\
\hline 70 & 0.1 & 31.42 & 76.73 & 1.21 & 2.65 & 2.92 & 224.276 & 0.910 & 595.20 & 470.24 & 79.01 \\
\hline 80 & 0.2 & 47.12 & 92.85 & 1.23 & 2.07 & 2.41 & 224.278 & 0.860 & 464.47 & 339.51 & 73.10 \\
\hline 90 & 0.3 & 62.83 & 109.76 & 1.17 & 1.67 & 2.04 & 224.278 & 0.818 & 373.98 & 249.02 & 66.59 \\
\hline 100 & 0.4 & 78.54 & 127.16 & 1.09 & 1.38 & 1.76 & 224.279 & 0.785 & 309.73 & 184.77 & 59.66 \\
\hline 110 & 0.5 & 94.25 & 144.85 & 1.01 & 1.17 & 1.54 & 224.279 & 0.758 & 262.62 & 137.67 & 52.42 \\
\hline 120 & 0.6 & 109.96 & 162.76 & 0.93 & 1.01 & 1.38 & 224.279 & 0.736 & 227.00 & 102.05 & 44.95 \\
\hline
\end{tabular}


Agar hubungan antara parameter yang dianalisis dapat dilihat dengan lebih jelas maka hasil perhitungan dalam Tabel 4 dan 5 disajikan kembali dalam bentuk grafik pada Gambar 8-10.

Gambar 8(a) memperlihatkan sebagian grafik $V$ beban $R_{\mathrm{L}}$ dan $Z \mathrm{~L}$ saling berimpit. Namun beban $R \mathrm{~L}$ mengalirkan $I_{\mathrm{a}}$ sedikit lebih tinggi dibanding beban $Z_{\mathrm{L}}$ menyebabkan tegangan jatuh yang merupakan fungsi dari $I_{\mathrm{a}}, R_{1}, X_{\mathrm{sd}}$ dan $X_{\mathrm{sq}}$ dalam Persamaan (24) menjadi lebih tinggi akibatnya tegangan terminalnya menjadi lebih rendah. Namun pada beban $R_{\mathrm{L}}, I_{\mathrm{aq}}=I_{\mathrm{a}}$, menghasilkan faktor daya $\cos \psi=1$. Dengan faktor daya yang lebih tinggi, daya keluaran $P_{\mathrm{o}}$ pada beban $R_{\mathrm{L}}$ juga lebih tinggi (Gambar 8(b)).

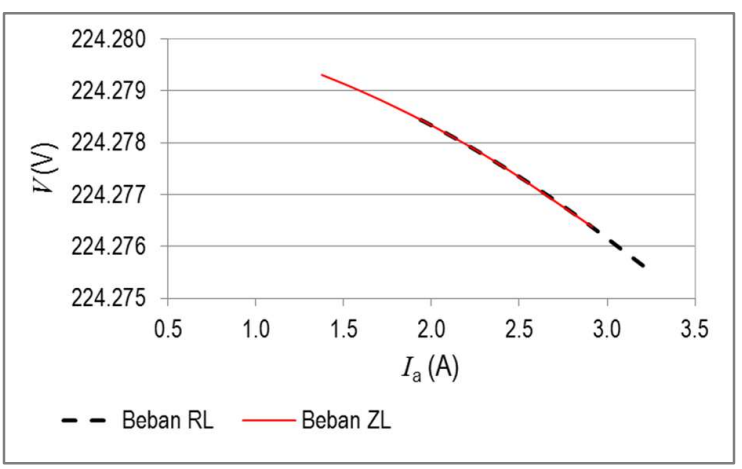

(a)

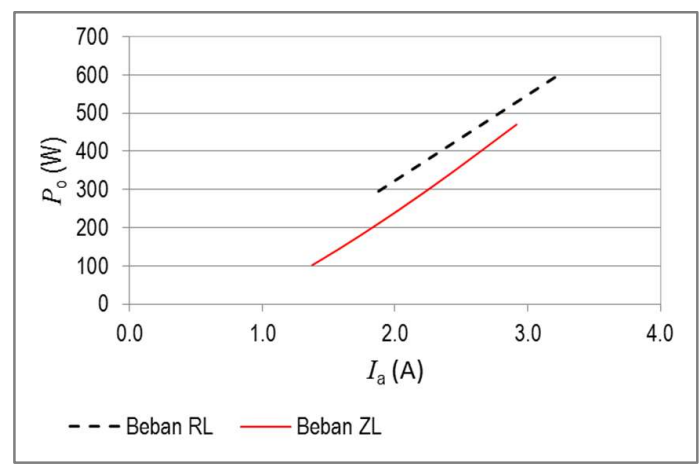

(b)

\section{Gambar 8. Karakteristik GMPFA pada Beban $R_{L}$ dan $Z_{L},(a)$ Tegangan Terminal $V_{l}$ (b) Daya} Keluaran $\boldsymbol{P}_{\mathbf{0}}$

Gambar 9 menjelaskan pengaruh penambahan beban induktansi pada pada beban $Z$ terhadap faktor daya dan memperlihatkan hubungan terbalik antara kedua parameter tersebut.

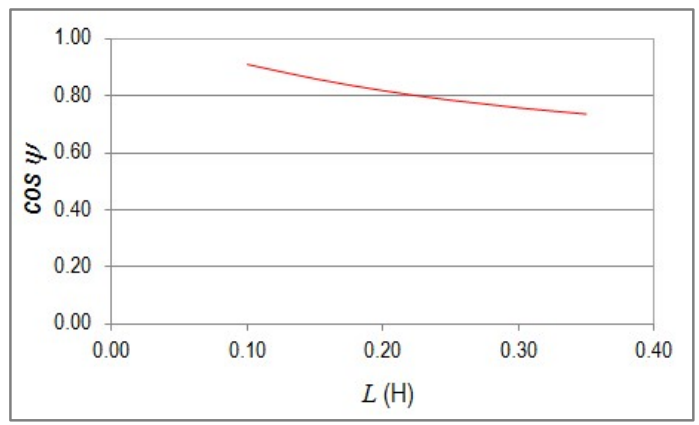

Gambar 9. Faktor Daya Cos $\psi$ Fungsi $L$

Dengan faktor daya yang lebih baik, generator dengan beban $R \mathrm{~L}$ menghasilkan efisiensi yang lebih tinggi dibanding dengan beban $Z$ L seperti diperlihatkan pada Gambar 10. 


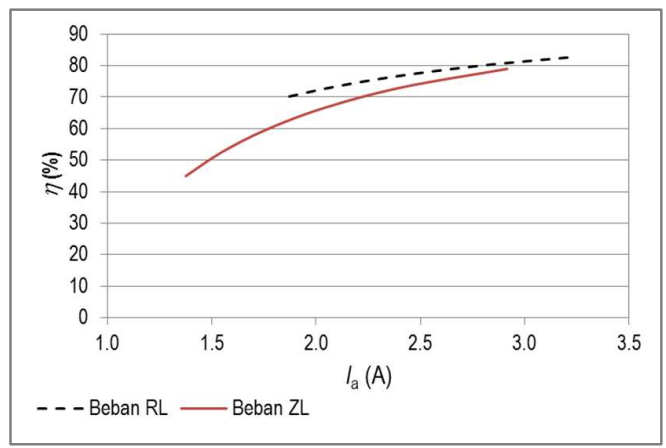

Gambar 10. Efisiensi $\eta$ Pada Beban $\boldsymbol{R}_{\mathrm{L}}$ dan $\boldsymbol{Z}$

Pada kedua jenis pembebanan, efisiensi generator makin tinggi ketika arus beban mendekati arus nominal. Kurva efisiensi pada beban $R_{\mathrm{L}}$ lebih landai disebabkan faktor dayanya konstan $=1$. Sementara itu, kurva efisiensi dengan beban $Z_{\mathrm{L}}$ memperlihatkan penurunan yang lebih curam ketika arus beban semakin menjauhi arus nominal atau ketika beban semakin induktif. Efisiensi maksimum hasil simulasi pada beban $R_{\mathrm{L}}$ dan $Z_{\mathrm{L}}$ masing-masing adalah $82.61 \%$ dan $79.01 \%$.

\section{KESIMPULAN}

Dalam makalah ini telah dibahas desain dan simulasi generator magnet permanen fluks aksial berbasis dimensi magnet permanen komersil. Generator memiliki konstruksi stator tunggal tanpa inti besi lunak dan rotor ganda dari bahan magnetik lunak baja karbon. Spesifikasi generator adalah $500 \mathrm{~W}, 220 \mathrm{~V}, 500 \mathrm{rpm}, 1$ fasa. Studi dimaksudkan untuk mengetahui performa generator ketika diberi beban $R_{\mathrm{L}}$ dan $Z_{\mathrm{L}}$. Hasil simulasi menunjukkan bahwa pada beban $R_{\mathrm{L}}$, generator menghasilkan daya keluaran dan efisiensi yang lebih tinggi dibanding pada beban $Z_{\mathrm{L}}$, masing-masing besarnya adalah $593.61 \mathrm{~W}$ dan $82.61 \%$. Sementara itu grafik karakteristik tegangan terminal pada kedua jenis beban tersebut sebagian berimpit tetapi pada beban $R_{\mathrm{L}}$ tingkat penurunannya lebih besar karena tegangan jatuhnya lebih tinggi. Dari semua hasil perhitungan dan simulasi dapat disimpulkan bahwa performa generator cukup baik dengan efisiensi sekitar $80 \%$ pada kedua jenis pembebanan.

\section{DAFTAR RUJUKAN}

Boldea, I. (2006). Synchronous Generator. USA: CRC Press.

Dalcali, A., \& Akbaba, M. (2017). Optimum Pole Arc Offset in Permanent Magnet Synchronous Generators for Obtaining Lowest Voltage Harmonics. Scientia Iranica D, 24 (6), 32233230.

Dewata, A., Bakar, A. S. A., \& Dwicahyo, K. (2015). Pemanfaatan WRF-ARW untuk Simulasi Potensi Angin Sebagai Sumber Energi di Teluk Bone. Jurnal Material dan Energi Indonesia, 5(2), $17-23$.

Dida, H. P., Suparman, S., \& Widhiyanuriyawan, D. (2016). Pemetaan Potensi Energi Angin di Perairan Indonesia Berdasarkan Data Satelit QuikScat dan WindSat. Jurnal Rekayasa Mesin, 7(2), 95-101. 
Gieras, J. F. (2010). Permanent Magnet Motor Technology: Design and Application (Third ed.). US: CRC Press.

Gieras, J. F., Wang, R.-J., \& Kamper, M. J. (2008). Axial Flux Permanent Magnet Brushless Machines (2nd ed.). Berlin: Springer.

Irasari, P., Alam, H. S., \& Kasim, M. (2013). Analytical Design Method of 3 KW, 200 rpm Permanent Magnet Generator for Renewable Energy Power Plant. Ketenagalistrikan dan Energi Terbarukan, 2(1), 55-66.

Kasim, M., Irasari, P., \& Hikmawan, M. F. (2016). Design, Simulation and Analysis of 3 kW Low Speed Axial Flux Permanent Magnet Generator. AIP Conference, (pp. 050004-1 050004-11)

Kasim, M., Irasari, P., Hikmawan, M. F., Widiyanto, P., \& Wirtayasa, K. (2016). Effect of Air Gap Variation on the Performance of Single Stator Single Rotor Axial Flux Permanent Magnet Generator. ICMSC, (pp. 060001-1 - 060001-9)

Nakhoda, Y. I., \& Saleh, C. (2016). Rancang Bangun Generator Magnet Permanen untuk Pembangkit Tenaga Listrik Skala Kecil Menggunakan Kincir Angin Savonius Portabel. Jurnal SETRUM, $5(2)$, 71-76.

Robiansyah, M. R. (2017). Perancangan Kontroler untuk Turbin Angin Skala Kecil. Seminar Nasional Teknoka, (pp. E6 - E15).

Tumanski, S. (2011). Handbook of Magnetic Measurements (Series in Sensors) (1 ed.). Florida: CRC Press.

Wijaya, F. D., W, Y. S., \& Nugroho, R. A. (2014). Perancangan Generator Magnet Permanen Fluks Aksial Putaran Rendah. Annual Engineering Seminar, (pp. B-21 - B-26).

Wirtayasa, K., Irasari, P., Kasim, M., Widiyanto, P., \& Hikmawan, M. (2017). Design of An Axial-Flux Permanent-Magnet Generator (AFPMG) 1 kW, 220 Volt, 300 rpm,1 Phase for Pico Hydro Power Plants. International Conference on Sustainable Energy Engineering and Application, (pp. 172 - 179) 